Sandupama, A.V.P.U., Ramachandra, T. and Madushika, U.G.D., 2021. Enhancing value engineering application in the Sri Lankan building construction industry: A framework. In: Sandanayake, Y.G., Gunatilake, S. and Waidyasekara, K.G.A.S. (eds). Proceedings of the $9^{\text {th }}$ World Construction Symposium, 9-10 July 2021, Sri Lanka. [Online]. pp. 314-325. DOI: https://doi.org/10.31705/WCS.2021.27. Available from: https://ciobwcs.com/papers/

\title{
ENHANCING VALUE ENGINEERING APPLICATION IN THE SRI LANKAN BUILDING CONSTRUCTION INDUSTRY: A FRAMEWORK
}

\author{
A.V.P.U. Sandupama ${ }^{1}$, T. Ramachandra ${ }^{2}$ and U.G.D. Madushika ${ }^{3}$
}

\begin{abstract}
The concept of value engineering (VE) is used to optimise the cost, time, quality, and functional performance toward achieving the best value for client money. However, the application of VE in construction industries is limited as there are differences in the use of the VE concept to developing economies, application of cost-oriented procurement systems, and lack of a practically applicable framework. In the local construction context, VE is practiced in an ad hoc manner. Therefore, the current study aimed to develop a framework including a tailored approach to enhance the VE application in the building construction industry. A qualitative approach was adapted to solicit views of twenty-two (22) construction professionals who involved in the six (6) high-rise building construction projects and practiced the VE concept. Views of professionals were synthesised using content analysis and finally developed a framework including a tailored VE approach. The findings conclude that cost and time as the main value criteria which motivate the VE application. Further, VE application in the construction industry is initiated mostly in the construction stages while professionals' preference is laid on the initial project phases. Consequently, the contractor change proposal was identified as the sound approach to deliver VE since motivations emerge during physical construction. Finally, a tailored VE approach was developed considering concept design, developed design, and construction stages with related VE motivations to enhance the VE application in the Sri Lankan building construction context in a simplified manner.
\end{abstract}

Keywords: Building construction; Strategies; Value criteria; Value engineering.

\section{INTRODUCTION}

Theoretically, Value Engineering (VE) is implemented as an innovative field for project performance optimisation (Chen and Su, 2017). Applying VE establishes a clear project objective and provides creative thinking for design improvement (Ahmed et al., 2016). Further, it contributes to reduces project cost by up to $26 \%$, enhances operational performance by $40-50 \%$, and upgrades product quality by 30-50\% (Gudem et al., 2013). Tohidi (2011) stated that the VE process enhances ways to deal with resource shortages,

\footnotetext{
${ }^{1}$ Department of Building Economics, University of Moratuwa, Sri Lanka, sandupamav@gmail.com

${ }^{2}$ Department of Building Economics, University of Moratuwa, Sri Lanka, thanujar@uom.lk

${ }^{3}$ Department of Building Economics, University of Moratuwa, Sri Lanka,

dilakshimadushika96@gmail.com
} 
minimise additional costs, and uses modern methods and practices. In addition, the VE application in the different stages of the construction works namely, feasibility study, design, construction, and maintenance throughout the life cycle generates optimum value (Shahhosseini et al., 2017). Reciprocally, Windapo (2013) stated the VE applies at any stage of the construction procedure since the generic requirement is to gain higher return through cost, time, and quality perspectives.

In the local context, the VE practices have not encouraged the theoretical aspects, practiced in an ad hoc manner without proper application of theoretical knowledge (Navarupan, 2004). Similarly, Senarathna (2013) stated that only a few instances had been reported on VE applications in the Sri Lankan context. Importantly, in several countries, there is a separate professional body; SAVE Local chapters or VE institutional bodies to establish the VE practices (Cheah and Ting, 2005). However, in the Sri Lankan construction industry, such requirement is not casted. Further, Sri Lankan VE practitioners consider VE as a cost-cutting mechanism initially used at the construction stage of a project, which is a common misconception on VE (Karunasena and Gamage, 2017). In addition, lack of client support, a misconception regarding the cost of implementation, lack of expert knowledge, unfamiliarity with the VE culture within public firms, and lack of construction framework and guidance to the practical application of the VE concept limits the VE application in Sri Lanka (Perera et al., 2003 ). Therefore, this study gives due consideration to facilitate construction professionals who work in building projects to identify value-enhancing gateways and simply understandable procedure to conduct VE study to enhance the application of VE practices in the Sri Lankan construction industry.

\section{LITERATURE REVIEW}

\subsection{VAlue ENGINEERING CONCEPT}

VE is considered an innovative and strategic approach used to achieve optimised value for money without reducing the quality, capabilities of operation, capabilities of maintenance, and aesthetic appearance (Othman, 2008; Yan et al., 2015). In addition, VE is considered as a subset of the Value Management (VM) process which focused on the technical process by translating built facility requirements using design and construction (Kelly et al., 2004). VM evolved through value analysis (VA), which caused the origination of the VE concept in the construction and industrial sectors (Shen and Liu, 2004). Further, the VM process can be illustrated in three stages as VA, VE, and value review (VR) respectively as illustrated in Figure 1.

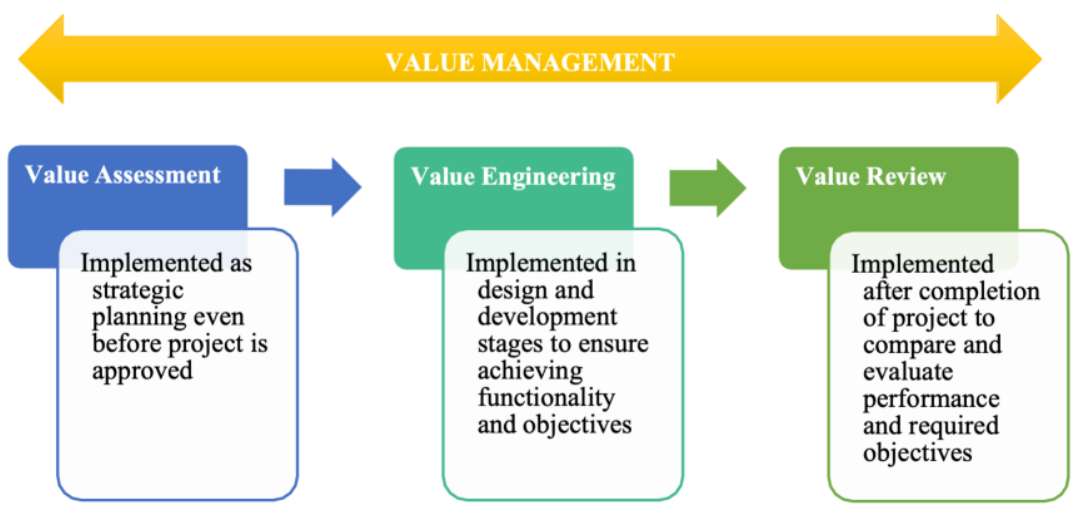

Figure 1: VM process (Adapted from Jaapar et al., 2012) 
Table 1 illustrates the common VE job plans that apply in the construction industry.

Table 1: VE approaches in the global context

\begin{tabular}{ll}
\hline \multicolumn{1}{c}{ VE Approach } & \multicolumn{1}{c}{ Description } \\
\hline Charette job plan & $\begin{array}{l}\text { This is used primarily for function analysis on requirements of space to } \\
\text { reasoning the client's brief. Considering the allocation of time this study } \\
\text { can be enhanced with other problems concerned in the client's brief. } \\
\text { This is not an expensive method of briefing the design team and } \\
\text { providing solutions to their requirements effectively and in a shorter } \\
\text { duration of two days }\end{array}$ \\
$\begin{array}{l}\text { This job plan is conducted over five days. This job plan is considered a } \\
\text { widely accepted formal approach comprised of three stages namely, pre- }\end{array}$ \\
$\begin{array}{l}\text { Workshop } \\
\text { Contractor's }\end{array}$ & $\begin{array}{l}\text { This job plan is a well-established form of carrying out the VM in the } \\
\text { change proposal } \\
\text { CE audit }\end{array}$ \\
& $\begin{array}{l}\text { In this approach, the external VE team engaged in the project to identify } \\
\text { VE proposals by reviewing the designs. }\end{array}$ \\
\hline
\end{tabular}

(Source: Kelly and Male, 2001)

Value attributes in VE concerned in the building construction industry evolved from the concept of the product to process as illustrates in Figure 2.

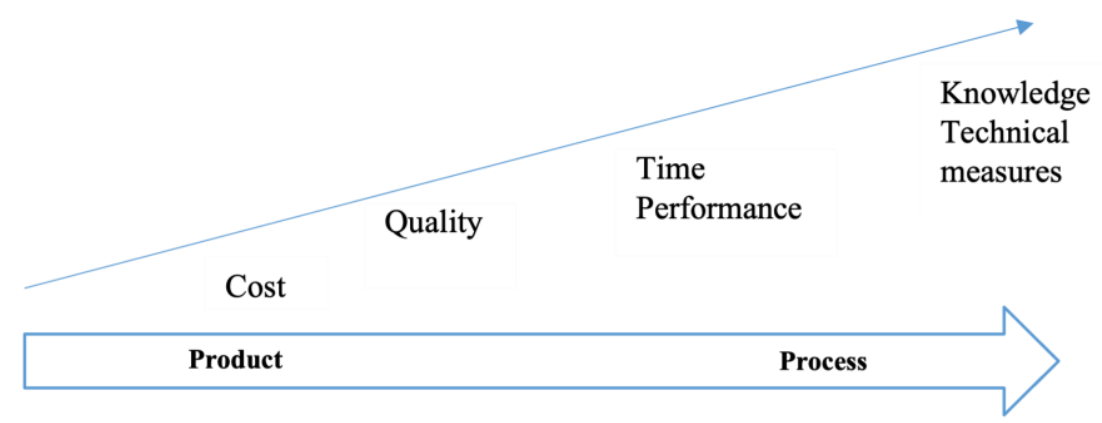

Figure 2: Value focus evolved over time (Adapted from: Dallas, 2006)

\subsection{BARRIERS AND CHALLENGES FOR IMPLEMENTING VALUE ENGINEERING}

According to Kosala and Karunasena (2015), one of the main objectives of Sri Lankan construction practitioners is to reduce the cost but not to enhance the value of the construction work. Thus, there is a requirement of redesigning due to the final design is mostly laid towards cost overruns (Perera et al., 2003). Other than the above poor perception of construction practitioners regarding the VE concept, the general application of VE to practical situations is restricted due to many reasons, which can be categorised as in Table 2. 
Table 2: Challenges to implement VE in developing countries

\begin{tabular}{|c|c|}
\hline Component & Specific factors contain \\
\hline $\begin{array}{l}\text { Obstructions of } \\
\text { VE team }\end{array}$ & $\begin{array}{l}\text { Lack of Client support } \\
\text { Difficulties to implementation } \\
\text { Misconception regarding the cost of implementation } \\
\text { Less teamwork spirits }\end{array}$ \\
\hline $\begin{array}{l}\text { Obstructions of } \\
\text { VE study }\end{array}$ & $\begin{array}{l}\text { Lack of expert knowledge } \\
\text { Overestimation of VE by stakeholders } \\
\text { Reluctance to resource utilization efficiently } \\
\text { Lack of construction framework and guidance to practical application } \\
\text { Unfamiliarity with the VE culture within public firms }\end{array}$ \\
\hline $\begin{array}{l}\text { Difficulties of } \\
\text { implementing VE }\end{array}$ & $\begin{array}{l}\text { Use of procurement systems that are cost-oriented } \\
\text { No willingness to apply VE } \\
\text { The impression that VE is not a worthy application } \\
\text { Conceptual provisions are inflexible } \\
\text { Lack of support from the strategic management and government } \\
\text { Lack of awareness of VE }\end{array}$ \\
\hline $\begin{array}{l}\text { Conceptual } \\
\text { problems }\end{array}$ & $\begin{array}{l}\text { Complicatedness and theoretical contents in VE } \\
\text { Consider VE is not required when the project is designed by the best } \\
\text { designers } \\
\text { Unsoundness to allocate time for VE }\end{array}$ \\
\hline $\begin{array}{l}\text { Obstructions due } \\
\text { to developing } \\
\text { economies }\end{array}$ & $\begin{array}{l}\text { VE is not being tallied with concepts of developing countries } \\
\text { Lack of awareness and knowledge on methodology } \\
\text { Insensitivity to take a risk and be creative }\end{array}$ \\
\hline
\end{tabular}

(Sources: Perera et al., 2003; Cheah and Ting, 2005; Chen and Su, 2017)

\subsection{VALUE ENGINEERING PRACTICE IN THE CONSTRUCTION INDUSTRY}

Table 3 provides the international VE practices.

Table 3. The international practice of $V E$

\begin{tabular}{|c|c|}
\hline Item & International practice \\
\hline Objectives of VE studies & $\begin{array}{l}\text { Existing and/or proposed projects or products related to both } \\
\text { strategic and tactical problems }\end{array}$ \\
\hline VE studies facilitator & Independent external or internal VE expert \\
\hline VE studies timing & From the conceptual stage to completion of a project or product \\
\hline Composition of VE team & Stakeholders relative and often many personnel are involved \\
\hline The workshop-style of VE & Preferred continuous and concentrated workshops \\
\hline Functional analysis & $\begin{array}{l}\text { Purpose of clarifying client's requirements and to identify poor } \\
\text { value by understanding the value system }\end{array}$ \\
\hline Duration & Generally, takes only a few days \\
\hline
\end{tabular}

(Adapted from: Shen and Liu, 2004) 


\section{RESEARCH METHODS}

In order to achieve the aim of this study, which is to develop a framework including a tailored approach to enhance the VE application in the Sri Lankan building construction context, a qualitative approach has been undertaken. Six (6) case studies have been conducted in high-rise building construction (above 4 storeys) projects where VE was applied within its project lifetime by giving the constraints of time and accessibility. All these identified cases were based on the traditional procurement methods. Subsequently, semi-structured interviews were conducted with the three or more respondents from each project from different professional disciplines. All together twenty-two (22) semistructured interviews were conducted (identified as I01 to I22). Figure 3 demonstrates the professional profile and experience of interviewees.
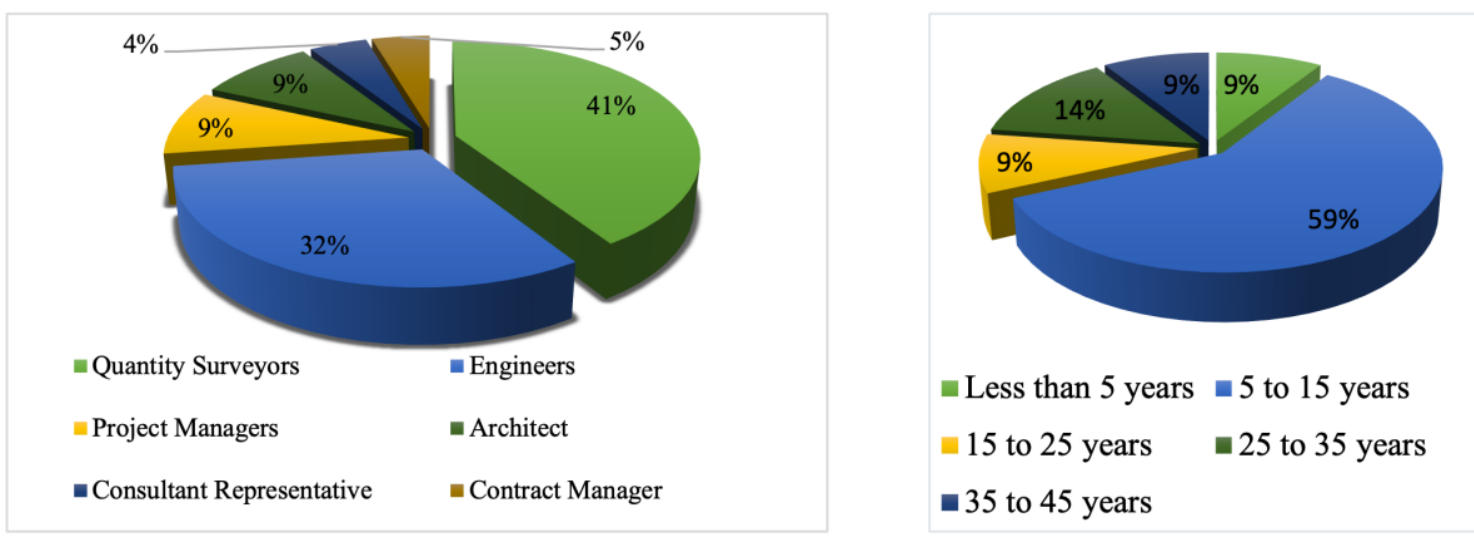

Figure 3: Profiles of professions and construction experience of interviewees

As seen in Figure 3, the majority of the respondents were Quantity Surveyors (41\%) and Engineers (32\%). In addition, most of the respondents had construction experience of around 5 to 15 years including VE practices.

Data analysis has been undertaken by using manual content analysis and NVivo 12 software. Ultimately, a framework has been developed including a tailored VE approach to enhance the VE application in the Sri Lankan building construction context through a comprehensive literature review and case study findings.

\section{DATA ANALYSIS AND FINDINGS}

\subsection{Details OF VE Proposals}

Table 4 shows the VE proposals that have been carried out within the selected cases. Nature, motivation, and achievements in terms of cost and time saving through the VE proposal in each project are drawn in Table 3.

According to the findings, identified VE proposals named PA1, PA3, PC3, PD1, PE3 were conducted with the main motivation of initial cost saving. In addition, PC1 and PC2 were considered the LCC concerned as major motivational factors. Further, VE proposals PA1, PA2, PA3, PB1, PE1, and PE2 were influenced to reduce the time consumption of the construction. 
Table 4: Details of VE proposals

\begin{tabular}{|c|c|c|c|c|c|c|c|}
\hline \multirow{2}{*}{ 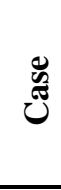 } & \multirow{2}{*}{ 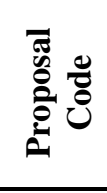 } & \multirow[t]{2}{*}{$\begin{array}{c}\text { Motivation(s) for } \mathrm{VE} \\
\text { proposal }\end{array}$} & \multirow[t]{2}{*}{ Description } & \multirow{2}{*}{\multicolumn{2}{|c|}{$\begin{array}{c}\begin{array}{c}\text { Cost } \\
\text { before }\end{array} \\
\begin{array}{c}\text { Cost } \\
\text { after }\end{array} \\
\text { Application of } \\
\text { VE (US\$ Mn) }\end{array}$}} & \multirow[t]{2}{*}{ Cost } & \multirow[t]{2}{*}{ Time } \\
\hline & & & & & & & \\
\hline \multirow[t]{3}{*}{ A } & PA1 & $\begin{array}{l}\text { Initial cost-saving/ } \\
\text { Contractor identified } \\
\text { an opportunity to } \\
\text { optimise project value }\end{array}$ & $\begin{array}{l}\text { Replacement of natural } \\
\text { marble and granite tiles } \\
\text { with porcelain tiles }\end{array}$ & 0.30 & 0.10 & $67 \%$ & $\sqrt{ }$ \\
\hline & PA2 & $\begin{array}{l}\text { Reuse usage/ } \\
\text { Contractor's } \\
\text { familiarisation to the } \\
\text { design }\end{array}$ & $\begin{array}{l}\text { Use MFE Aluminium } \\
\text { formwork system instead } \\
\text { of traditional formwork }\end{array}$ & 0.067 & 0.044 & $34 \%$ & $\sqrt{ }$ \\
\hline & PA3 & $\begin{array}{l}\text { Cost-saving/ Enhance } \\
\text { construction efficiency }\end{array}$ & $\begin{array}{l}\text { Stainless steel handrail to } \\
\text { mild steel handrail }\end{array}$ & 0.51 & 0.35 & $32 \%$ & $\sqrt{ }$ \\
\hline B & PB1 & $\begin{array}{l}\text { Time saving/Space } \\
\text { optimisation/Constructi } \\
\text { on efficiency }\end{array}$ & $\begin{array}{l}\text { Changing the vent pipe } \\
\text { size from } 150 \mathrm{~mm} \text { to } \\
100 \mathrm{~mm}\end{array}$ & 0.089 & 0.05 & $43 \%$ & $\sqrt{ }$ \\
\hline \multirow[t]{3}{*}{$\mathrm{C}$} & PC1 & $\begin{array}{l}\text { LCC consideration/ } \\
\text { New technologies }\end{array}$ & $\begin{array}{l}\text { Replacement of traditional } \\
\text { chiller system to Smart } \\
\text { magnetic bearing chiller } \\
\text { system }\end{array}$ & 1.26 & 0.90 & $28.5 \%$ & - \\
\hline & $\mathrm{PC} 2$ & $\begin{array}{l}\text { LCC consideration/ } \\
\text { New technologies }\end{array}$ & $\begin{array}{l}\text { Changing the electrical } \\
\text { system - Power generation }\end{array}$ & \multicolumn{4}{|c|}{$\begin{array}{c}\text { This proposal was not } \\
\text { implemented }\end{array}$} \\
\hline & PC3 & $\begin{array}{l}\text { Cost-saving/New } \\
\text { technologies }\end{array}$ & $\begin{array}{l}\text { Changing the interior } \\
\text { decoration }\end{array}$ & \multicolumn{4}{|c|}{$\begin{array}{c}\text { This proposal was not } \\
\text { implemented }\end{array}$} \\
\hline $\mathrm{D}$ & PD1 & $\begin{array}{l}\text { Cost-saving/New } \\
\text { technologies }\end{array}$ & $\begin{array}{l}\text { Changing the internal wall } \\
\text { cladding thickness from } \\
10 \mathrm{~mm} \text { to } 8 \mathrm{~mm}\end{array}$ & 1.72 & 1.20 & $10.98 \%$ & - \\
\hline \multirow[t]{3}{*}{$\mathrm{E}$} & PE1 & $\begin{array}{l}\text { Optimise project } \\
\text { Budget/Contractor } \\
\text { identified opportunity } \\
\text { to optimise project } \\
\text { value }\end{array}$ & $\begin{array}{l}\text { Use skim coat special } \\
\text { finishing instead of granite } \\
\text { cladding }\end{array}$ & 0.74 & 0.26 & $65 \%$ & $\sqrt{ }$ \\
\hline & PE2 & $\begin{array}{l}\text { Due to regulation } \\
\text { requirements }\end{array}$ & $\begin{array}{l}\text { Change the sprinkler } \\
\text { system design according to } \\
\text { the requirement }\end{array}$ & 7.44 & 7.22 & $3 \%$ & $\sqrt{ }$ \\
\hline & PE3 & $\begin{array}{l}\text { Initial cost-saving/ } \\
\text { Construction efficiency }\end{array}$ & $\begin{array}{l}\text { Electrical Aluminium } \\
\text { cables instead of Copper } \\
\text { cables }\end{array}$ & 1.65 & 1.46 & $12 \%$ & $x$ \\
\hline $\mathrm{F}$ & PF1 & $\begin{array}{l}\text { Land restrictions/Due } \\
\text { to adjacent } \\
\text { constructions/ } \\
\text { Unnecessary indirect } \\
\text { cost in construction }\end{array}$ & $\begin{array}{l}\text { Changing the piling } \\
\text { foundation to raft } \\
\text { foundation }\end{array}$ & 0.31 & 0.22 & $31 \%$ & - \\
\hline
\end{tabular}

Interviewee I07 who stated that PB1 was motivated to implement excess time requirements due to constructability issues facilitated that statement. However, as identified through the VE proposal PF1, that it was not motivated to minimise the time for construction, but the VE proposal indirectly causes to reduce construction time consumption. Even though any of these selected cases were not motivated to increase 
quality, interviewee I18 stated that cheap material options could not be considered as VE proposals because they can influence quality reductions. In other terms, I19 stated VE could be used adhering to the regulations and standards related to the building construction to maintain the quality requirements.

\subsection{Value Engineering in Different Project Phases}

Figures 4 and 5 demonstrate the project phases that applied the VE concept in the selected cases and the results of the interviews, respectively.

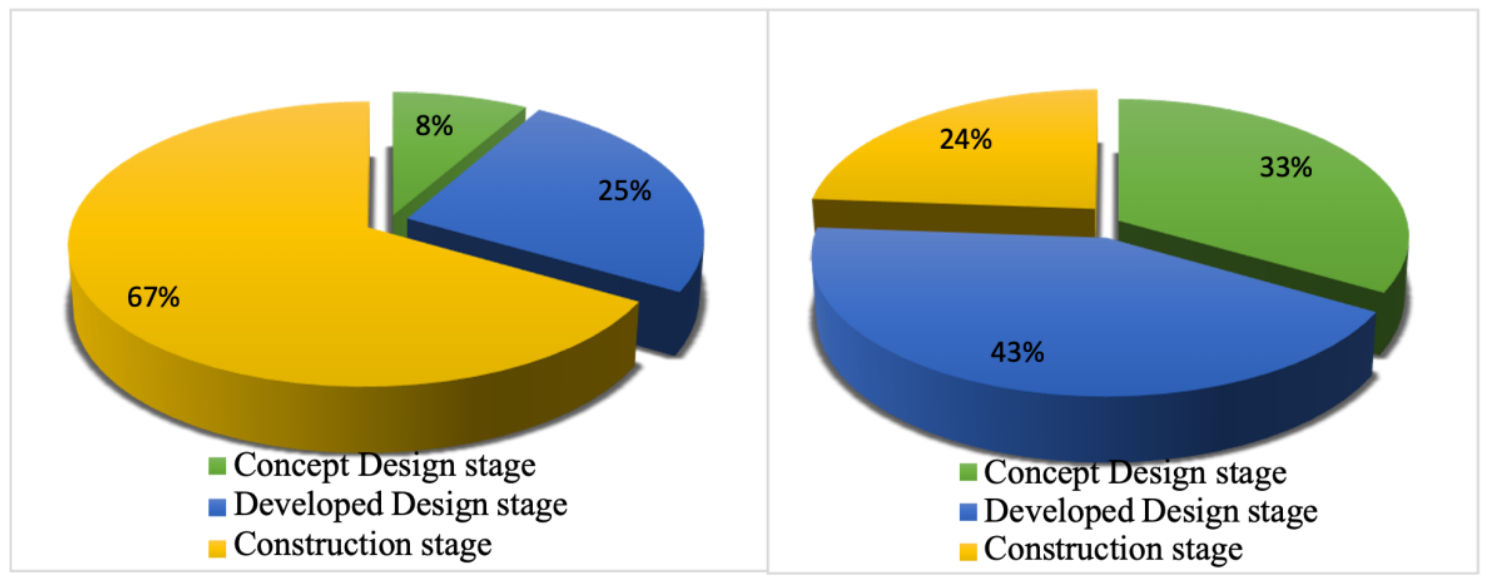

Figure 4: Project phases of VE applied

Figure 5: Preferred VE applicable phases

The majority of the VE proposals (67\%) selected for the study carried out in the construction stage and $25 \%$ and $8 \%$ of VE proposals were applicable in the developing design stage and concept design stages, respectively. However, according to the views of respondents (44\%), the developed design stage was identified as the most preferable project phase to apply VE proposals while the least preference (24\%) was laid on the construction stage.

\subsection{VAlue Engineering APPROAChes In the Local CONTEXT}

Figures 6 and 7 demonstrate the VE approaches applied in the selected VE proposals and the results of the interviews, respectively.

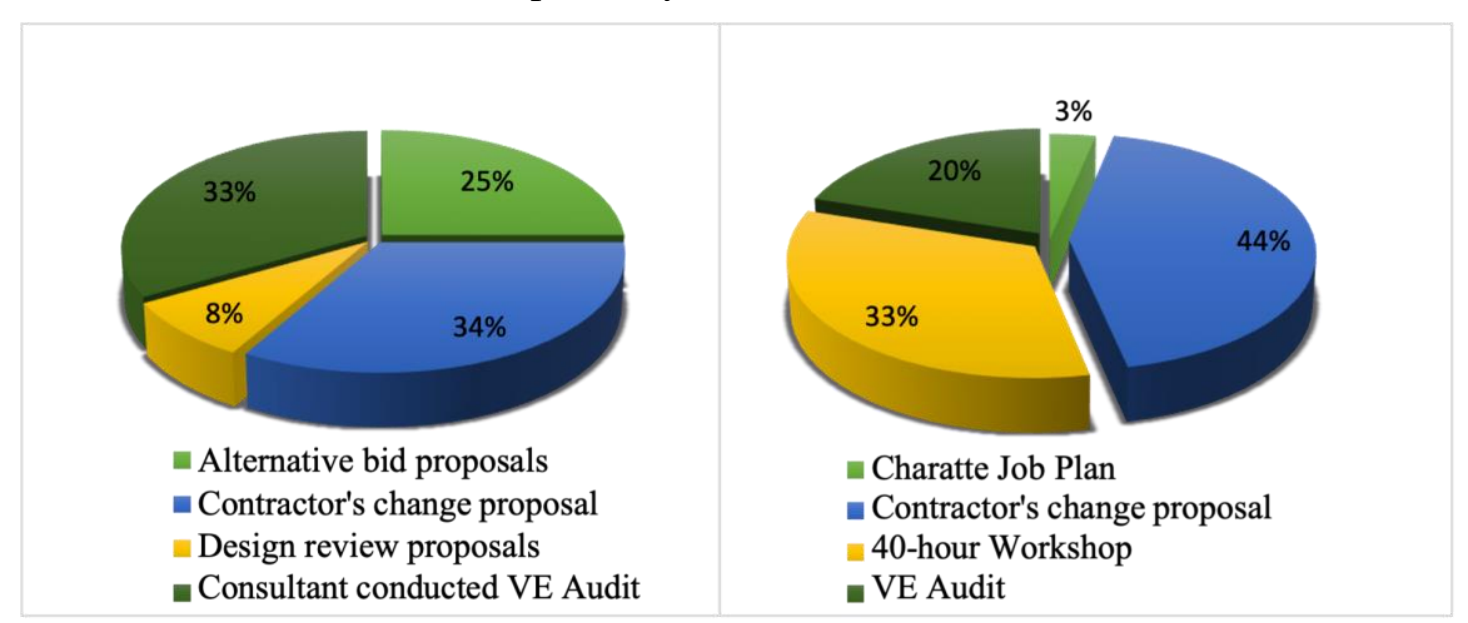

Figure 6: Applied VE approaches

Figure 7: Preferred applicable VE approaches 
According to the respondents, contractor's change proposals were most applicable (34\%) and most preferable (44\%) to the local construction industry. Most of the theoretical VE approaches were unaware of by the construction professionals. However, nearly half of the interviewees were aware of the VE workshop, and they recommended VE 40-hour workshop (33\%) as one of the preferred approaches to the Sri Lankan construction industry. Above a quarter of the respondents stated, the risk resistance is very high in Sri Lanka due to the professionals' traditional thinking pattern. Therefore, implementing VE required considerably high force. Even though, selecting a preferred VE approach would be very obstructive within such background. Nevertheless, currently, the construction practice can easily implement the contractor's change proposal method. Following are the causations to the selection of the contractor's change proposal as the sound approach to deliver VE in the local construction context:

- Local construction is mostly cost concerned and when contracts identify any cost overrun within the project can use VE as a tool to reduce such budget overrun from another dimension.

- Generally, separate time is not allowed to practice VE.

- Consultancy services were not used to crave the optimum facilities required for the building constructions.

\subsection{Challenges AND Strategies to Enhance VAlue EngineERING APPLICATION IN SRI LANKA}

Table 5 presents the specific challenges in implementing VE in project phases of selected cases.

Table 5: VE application challenges identified in each project phases

\begin{tabular}{ll}
\hline \multicolumn{1}{c}{ Project Phase } & \multicolumn{1}{c}{ Challenges to applying VE } \\
\hline $\begin{array}{l}\text { Strategic definition and } \\
\text { preparation of client brief } \\
\text { stages }\end{array}$ & $\begin{array}{l}\text { The opinion of professionals is these changes are initial } \\
\text { changes to the original design (I03, I06, I11, I15, I17) }\end{array}$ \\
Concept design stage & $\begin{array}{l}\text { Generally, Architect does not agree to change their design } \\
\text { (I02, I03, I07, I10, I19, I21) } \\
\text { The client will not approve these value-adding } \\
\text { opportunities while resisting to take risks (I01, I05, I11, } \\
\text { I12, I16, I18, I20, I22) } \\
\text { In some projects, bidders were called to submit alternative } \\
\text { proposals, which has the potential of VE. Eventhough this } \\
\text { is not conducted properly due to unethical practices (I07, } \\
\text { I12, I13, I15, I16) } \\
\text { Contractor's do not tend to take the responsibility (I01, I10, } \\
\text { I12, I14, I17) }\end{array}$ \\
\hline
\end{tabular}

Interviewees I09, I12, I18 and I22 expressed that in most of the building construction projects conducted in the Sri Lankan context, the main stakeholder or the client is a nonprofessional who does not aware about the tools and techniques that used to optimise the value of the construction facility.

According to the majority of the interviewees (36\%), improve the awareness among construction professionals identified as the critical requirement to enhance the VE 
application in the Sri Lankan construction industry. Thereafter, most of the responses (32\%) accept that initial insist through advantages of the VE practices as a secondly suitable way to enhance the VE approach. Then three strategies were identified which are enhance rules and regulations by the government, promote long-term benefits, and reviewing the design throughout design and construction stages as the third most important through the opinions of the professionals (27\%). In addition, VE encouragement through current practices, enhance client end technology in the construction sector, ensure VE approaches not effecting time expansions, conducting brainstorming sessions, integrate separate VE team to construction projects, and introduce clear mechanism to reward parties who identify VE are also identified as the strategies to enhance VE application through findings.

\subsection{DEVELOPMENT OF THE FRAMEWORK}

The framework was developed to enhance the VE application in the Sri Lankan construction industry (see Figure 8). The framework identifies the motivations in the current construction industry and the most applicable project phases to implement VE due to the identified motivations or value criteria in this research study. Other than that, simplified tailored VE job plans were implemented using the analysis to enhance the construction professionals' attraction towards the standard VE practices. Moreover, barriers of VE application in standard and enhance focuses were addressed to mitigate with the suggestions. The framework was developed to distil the VE applications from a simplified perspective.

\section{DISCUSSION}

From the research findings, cost and time were identified as the main value criteria which were motivated the VE application. The results of Kim and Luu-Truong (2016) coincide with this finding. Though the quality aspect was not motivated by the VE application in the selected cases, interviewees stated that quality is a compulsory requirement. With a similar perspective, Dallas (2006) stated that quality performance is one of the value criteria which evolvedover the value focus in the construction industry. In terms of the application of VE proposals, literature identified in most of the circumstances VE is better to apply inthe initial project phases to obtain more benefits (Abidin and Pasquire, 2007). However, the research findings identified that interviewees mostly preferred to apply VE at the design stages because it minimises the changes that occurred to the design at later stages.

\section{CONCLUSIONS}

This research identified that the VE application in the local context is narrow to the standard VE practices. However, about the standard VE professionals were more or less knowledgeable due to conventional trends and conceptual problems in construction activities, professionals tend to informal VE practices. Therefore, the theoretical job plan is indirectly followed in an unstructured manner is the common feature identified from all the selected cases. Through this study identified the motivations in the current construction industry and the most applicable project phases to implement VE due to the identified motivations or value criteria. 


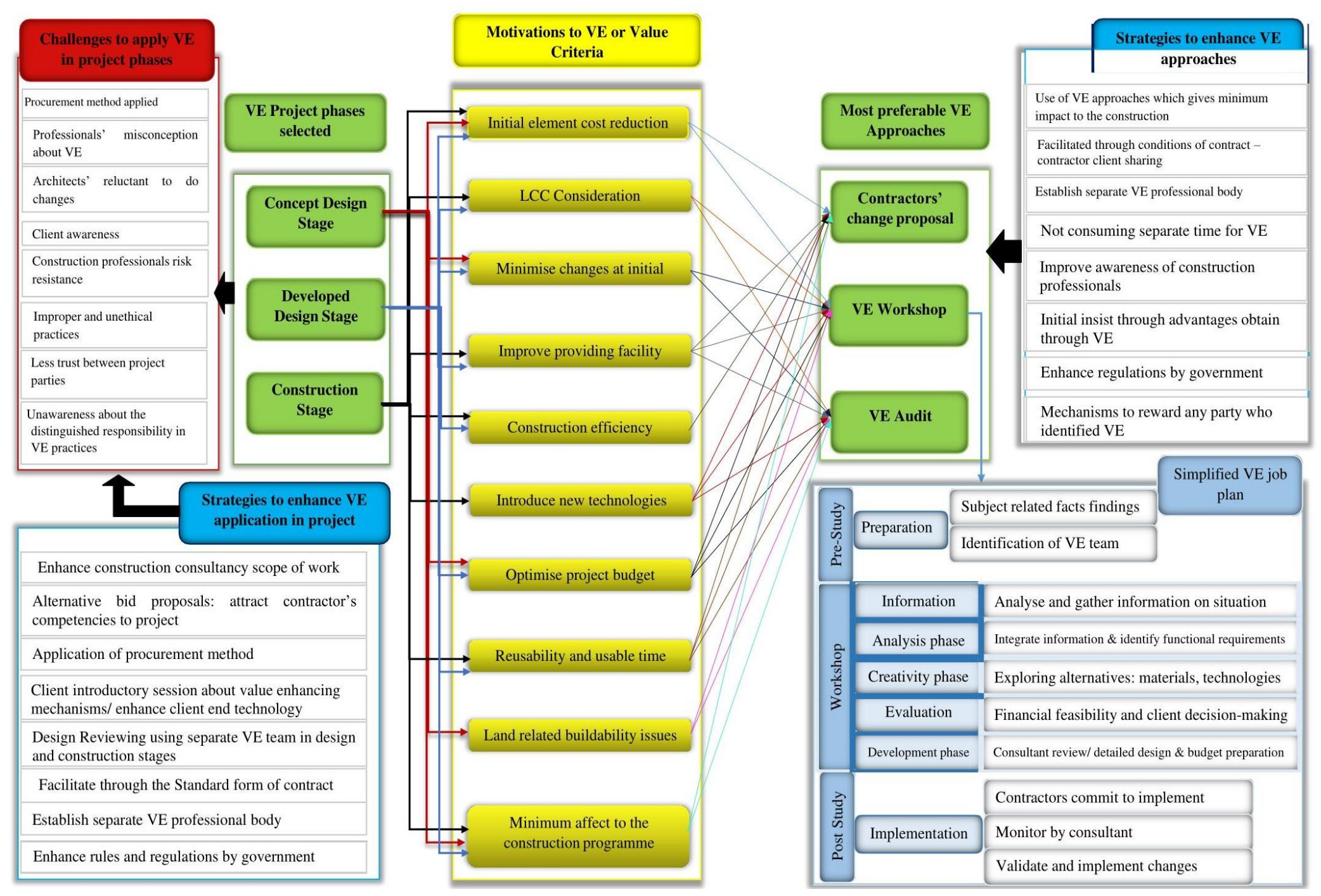

Figure 8: The framework to enhance the VE application in the Sri Lankan building construction context 
Considering these VE motivations and attractions of the professionals above tailored VE approach were designed compared to the theoretical VE job plan. Further, this study recommends that they should take actions to enhance construction professional's knowledge on VE while minimising the misconceptions on the VE objectives by conducting knowledge transfer sessions. Currently, VE applications mostly can be seen in the construction industry, however, steps should be taken to promote the VE application in the design stages to minimise the changes and cost incurred to such changes due to VE applications through the national intervention.

\section{REFERENCES}

Abidin, N.Z. and Pasquier, C.L., 2007. Revolutionize value management: A mode towards sustainability. International Journal of Project Management, 25(3), pp. 275-282.

Ahmed, K.A.A. and Pandey, R., 2016. Concept of value engineering in construction industry. International Journal of Science and Research, 5(4), pp. 1231-1237.

Cheah, C.Y. and Ting, S.K., 2005. Appraisal of value engineering in construction in Southeast Asia. International Journal of Project Management, 23(2), pp. 151-158.

Chen, T.T. and Su, T.C., 2017. Fuzzy-based decision-making applied to performance evaluation invalue engineering. Journal of the Chinese Institute of Engineers, 40(3), pp. 200-206.

Dallas, M.F., 2006. Value and Risk Management: A Guide to Best Practice. London: Wiley.

Gerhardt, D.J. and Rand, P.I., 2006. Managing value engineering in new product development. Value World, 29(2), p. 26.

Gudem, M., Steinert, M., Welo, T. and Leifer, L., 2013. Redefining customer value in lean product development design projects. Journal of Engineering, Design, and Technology, 11(1), pp. 71-89.

Jaapar, A., Zawawi, M., Bari, A. N. and Ahamad, N., 2012. Value management in the malaysian construction industry: Addressing a theory and practice gap. Procedia-Social and Behavioral Sciences, 35, pp. 757-763.

Karunasena, G. and Gamage, R.K., 2017. A decision-making formula for value engineering applications in the Sri Lankan construction industry. Journal of Financial Management of Property and Construction, pp. 77-91.

Kelly, J., Male, S. and Graham, D., 2004. Value management of construction projects. London: Blackwell Science.

Kelly, S.R. and Male, S.P., 2001. Value management in design and construction: The economic management of project. London: E and FN Spon.

Kim, S.L. and Luu-Truong, L., 2016. Barriers to applying value management in the Vietnamese construction industry. Journal of Construction in Developing Countries, 21(2), pp. 55-80.

Kosala, R.G. and Karunasena, G., 2015. Value engineering practices and its impact on construction industry. Colombo, University of Moratuwa, Sri Lanka, pp. 538-546.

Mansour, A. and Abueusef, M., 2015. Value engineering in developing countries. Bali, Indonesia.

Navarupan, N., 2004. Application of value management in sri lankan construction industry. Sri Lanka: University of Moratuwa.

Othman, A. A., 2008. Incorporating value and risk management concepts in developing low-cost housing projects. Journal for Engineering Research, 13(1), pp. 45-52.

Perera, S., Karunasena, G. and Selvadurai, K., 2003. Application of value management in construction. Built Environment Sri Lanka, 4(1), pp. 3-12.

Senarathna, W., 2013. Development of a framework to integrate sustainable construction and value planning in Sri Lankan construction industry. Sri Lanka: University of Moratuwa.

Shahhosseini, V., Afshar, M.R. and Amiri, O., 2017. Value engineering practices in infrastructure projects: A case study of Ilam gas refinery's water transmission system at Reno mountain, Iran. International Journal of Construction Management, pp. 1-13. 
Shen, Q. and Liu, G., 2004. Applications of value management in the construction industry in China. Engineering Construction and Architectural Management, 11(1), pp. 9-19.

Tohidi, H., 2011. Review the benefits of using value engineering in information technology project management. Procedia Computer Science, 3, pp. 917-924.

Windapo, A. O., 2013. Value-Based perspectives of stakeholders' building requirements in low cost and government subsidised housing projects in South Africa. Construction Innovation: Information, Process, Management, 13(4), pp. 424-444.

Yan, Q.Y., Shen, H.J. and Kong, H., 2015. Assessing hotel cost control through value engineering: A case study on the budget hotels in a middle-sized city in China. Asia Pacific Journal of Tourism Research, 21(5), pp. 512-523. 